\title{
Benchmarking of viral bronchiolitis management by General Practitioners (GPs) in the UK
}

\section{Abstract}

Background Viral bronchiolitis is the leading cause of hospitalisation in infants in the UK with wide variation in rates of hospitalisation in different geographical regions of the UK. A potential cause of these differences is variation in primary care management and referral to hospital. This study aimed to prospectively survey General Practitioners (GPs) in the UK to provide a benchmark of practice against which future practice can be assessed.

Methods An electronic, structured questionnaire was sent to 1001 geographically representative GPs in primary care centres in the UK, via the market research company MedeConnect, to assess their management of infants with viral bronchiolitis. We measured practice before the 2015 NICE bronchiolitis guideline against the guideline, to obtain a benchmark of practice. We also used a multivariate analysis to assess GP factors associated with variation in management.

Results $39 \%$ of GPs did not refer to any guideline to manage infants with bronchiolitis, $33 \%$ did not routinely measure oxygen saturations, $48 \%$ prescribed an 'inappropriate' (evidence of no benefit) medication and $62 \%$ did not give written guidance to parents. GP factors influencing management included the year the GP qualified, sex, region of practice and working at a dispensing practice. Up to $75 \%$ of GPs' management did not conform to the newly published 2015 NICE bronchiolitis guideline prior to its publication. 
Conclusion There was wide variation in the management of infants with viral bronchiolitis by UK GPs. Most infants with viral bronchiolitis are not managed optimally by GPs and multiple GP factors influenced this management. 


\section{Introduction}

Viral bronchiolitis, especially that caused by respiratory syncytial virus (RSV), is the leading cause of hospitalisation in infants under a year old. More than 30,000 infants are hospitalised yearly in England and Wales due to viral bronchiolitis with a wide variation in rates of hospitalisation in different UK geographical regions. ${ }^{1}{ }^{3}$ No clear cause has been identified for this variation although potential factors include socioeconomic deprivation and differences in primary care referral and hospital admission guidelines. ${ }^{2}$

Management of bronchiolitis is purely supportive (oxygen supplementation and feeding support). There is evidence that medications including bronchodilators, steroids, leukotriene receptor antagonists and antibiotics ${ }^{4}{ }^{7}$ have no role in the vast majority of bronchiolitic infants. There are currently no vaccines for the viruses causing bronchiolitis, although several against RSV are in development. ${ }^{8}$ Passive immunisation with a monoclonal antibody (palivizumab) is available for high-risk infants.

The Scottish Intercollegiate Guideline Network (SIGN) published a guideline for managing infants with bronchiolitis in primary and secondary care in $2006^{9}$, but until $1^{\text {st }}$ June 2015 when the National Institute for Health and Care Excellence (NICE) published their guidance ${ }^{10}$ there was no national guidance in England and Wales. The guidance given by NICE and SIGN is very similar, with the main difference being the level of oxygen saturation requiring referral to hospital from primary care; $<95 \%$ in SIGN and $<92 \%$ in NICE. Individual GP surgeries 
have local guidelines often based on national (SIGN) or international (American Academy of Pediatrics [AAP]) guidelines but how variable these guidelines are in the United Kingdom (UK) National Health Service (NHS) is unknown.

The aim of this study was to prospectively survey General Practitioners (GPs) in the UK (England, Scotland, Wales and Northern Ireland) to provide a benchmark of practice prior to the publication of the 2015 NICE bronchiolitis guideline against which future practice can be assessed. We also aimed to investigate possible GP causes of any variation in management.

\section{Methods and Materials}

Over a two-week period in March 2015 an electronic, structured questionnaire based on the NICE bronchiolitis draft guideline, was sent to General Practitioners (GPs) registered with the General Medical Council in the UK and recruited by MedeConnect, the market research division of Doctors.net.uk. A sample of 1000 GPs stratified by UK geographic region was requested. MedeConnect sent invitations to members followed by reminders until 1000 GPs had completed the questionnaire. GPs were not aware of the topic of the questionnaire so it was not biased by being completed by GPs with an interest in paediatrics. Demographic data were collected from GPs and five research questions were included to investigate the management of infants with bronchiolitis (supplementary Box 1). 
We compared the proportions of GPs from individual countries (England, Wales, Scotland and Northern Ireland) who would be compliant with the NICE guideline. ${ }^{10}$ The NICE guideline ${ }^{10}$ suggests all infants should be referred to hospital if oxygen saturations are $<92 \%$ in air (if GPs did not assess oxygen saturations they were deemed non-compliant with the guideline) or if feeding is $<50-75 \%$ of normal (we considered feeding $<50 \%$ of normal an absolute referral criteria), antibiotics, inhaled bronchodilators, leukotriene receptor antagonists and steroids (oral/inhaled) should not be prescribed and parents should be provided with "key safety information to take away for reference" (we interpreted that as needing to provide written advice).

\section{Statistical analysis}

Proportions were compared using the Chi squared test or Fisher's exact test as appropriate. Post hoc testing was carried out using the Kruskal Wallis test of significance. A multivariate analysis, by means of a logistic regression model, was carried out on the dichotomised responses against the categorical covariates. Correlation coefficients were calculated to assess whether hospital admission rates in English NHS Strategic Health Authorities were influenced by various GP management factors. Statistical analysis was carried out with IBM SPSS Statistics (version 22, New York, USA).

This study did not require ethical approval.

\section{Results}


In total 1001 GPs completed the questionnaire, 552 (55\%) were male. Participants included 629 (63\%) GP principals, 252 (25\%) salaried GPs, 119 (12\%) locum GPs and one (0.1\%) trainee GP. Eighty-nine (9\%) qualified before 1980, 219 (22\%) between 1980-1989, 330 (33\%) between 1990-1999 and 363 (36\%) between 2000-2010. The median (range) number of GPs in each practice was six (1-30) and the median (range) GP practice size was 8100 (500$36,000)$ patients. One hundred and eighty-seven (19\%) GP practices were dispensing practices (i.e. had a pharmacy on site). The geographic areas where GPs practiced are shown in supplementary Table 1; $399(40 \%)$ were in urban areas, 254 (25\%) suburban areas, 238 (24\%) semi-rural areas, 102 $(10 \%)$ rural areas and eight (1\%) defined as 'other' areas (e.g. included prisons and university campuses).

Two hundred and ninety (29\%) GPs used a locally developed guideline, 248 (25\%) used a commercially available guideline (e.g. from an internet website, www.gpnotebook.co.uk), 227 (23\%) used a national guideline (i.e. SIGN) and $390(39 \%)$ did not use any guideline. Some GPs used more than one guideline. Supplementary figure 1 (a) shows the geographic variation in use of a guideline by GPs.

If there were no other indications for referral to hospital, four $(0.4 \%)$ GPs routinely referred bronchiolitic infants to hospital only if their oxygen saturations were $\leq 88 \%, 60(6 \%)$ at $\leq 90 \%, 250(25 \%)$ at $\leq 92 \%$ and $360(36 \%)$ at $\leq 94 \%$. Three hundred and twenty-seven (33\%) GPs did not test oxygen saturations on bronchiolitic infants. Supplementary figures 1(b) and 1(c) show the geographic 
variation in use of oxygen saturations by GPs and in guidelines for referral to hospital when oxygen saturations are $\leq 92 \%$ (including those who only refer if saturations are $\leq 92 \%, \leq 90 \%$ or $\leq 88 \%$ ).

If there were no other indications for referral to hospital, 145 (14\%) GPs routinely referred bronchiolitic infants to hospital only if they were feeding $<33 \%$ of normal, $564(56 \%)$ if feeding $<50 \%$ of normal, $190(19 \%)$ if feeding $<75 \%$ of normal and $14(1 \%)$ if feeding was anything less than normal. Supplementary figure $1(d)$ shows the geographic variation in referral to hospital if feeding $<50 \%$ of normal.

Three hundred and forty-nine (35\%) GPs routinely prescribed inhaled bronchodilators for bronchiolitic infants, 53 (5\%) inhaled steroids, 195 (19\%) oral steroids, $75(7 \%)$ oral antibiotics, $16(2 \%)$ oral leukotriene receptor antagonists, 224 (24\%) saline (or similar) nose drops and 435 (43\%) prescribed no medicines routinely. Supplementary figure $1(\mathrm{e})$ shows the geographic variation in use of 'inappropriate' medications (any of the above medications, excluding saline nasal drops, which should not be prescribed according to the NICE guideline).

One hundred and twenty-four (12\%) GPs routinely provided locally developed written guidance for parents of bronchiolitic infants, 99 (10\%) nationally developed guidance (e.g. the SIGN information leaflet), 156 (16\%) provided written guidance from another source and 622 (62\%) did not routinely provide 
written guidance. Supplementary figure 1 (f) shows the geographic variation in provision of written advice.

We compared the geographic variation with each of the above factors to the hospitalisation rate for bronchiolitis by NHS strategic health authority calculated in a study by Murray et al ${ }^{3}$ (supplementary figure 2 ). None of the above factors explained the variation in hospitalisation rate (all $P$ values $>0.05$, supplementary figures 1a-e).

Only $58 \%$ of GPs in Scotland, $62 \%$ in England, $57 \%$ in Wales and $44 \%$ in NI $(P=0.25)$ referred to any guideline for the management of infants with bronchiolitis. In Scotland 23\% used the SIGN guideline compared with $23 \%$ in England, $24 \%$ in Wales and $22 \%$ in $\mathrm{NI}(\mathrm{P}=0.99)$. Table 1 shows the current compliance with various aspects of the NICE guideline by the country in which the GP works. There were significant differences in the percentage of GPs prescribing inhaled bronchodilators $(P=0.01)$ and providing written advice $(P=0.03)$ between the four countries.

\section{Factors influencing management}

Multivariate logistic analysis was carried out on each dichotomous response to determine which covariates had the largest influence on the response when accounting for the influence of other covariates (supplementary table 3). The covariate which influenced most of the responses was the year in which a GP qualified. This covariate was significant in predicting whether a guideline was used, whether an infant was referred to hospital if feeding was $<50 \%$, whether 
oral steroids or antibiotics were prescribed, whether any 'inappropriate' medication was prescribed, and whether written advice was given. The region of the UK where the GP practice was located had a significant influence on the use of oxygen saturation monitoring, on whether salbutamol and saline nasal drops were prescribed, and on whether any 'inappropriate' medication was prescribed. Sex of the GP was significantly associated with whether an infant was referred if the oxygen saturations were $<92 \%$ and if feeding was $<50 \%$. Male GPs were more than twice as likely as females to refer infants to hospital only once the oxygen saturations were $<92 \%$ (odds ratio [OR] [95\% C.I.] 2.44 $[1.66 ; 3.32])$, and one and a half times more likely to refer infants to hospital only once the feeding was $<50 \%$ of normal (OR $1.48[1.10 ; 2.01]$ ). As the number of GPs in the practice increased, the likelihood of referring the infant to hospital only once their oxygen saturations were $<92 \%$ increased (OR 1.62 $[1.18 ; 2.22])$ and the odds of prescribing salbutamol decreased (OR 0.74 [0.57; 0.97]). Working in a dispensing practice was significantly associated with the prescription of oral leukotriene receptor antagonists (e.g. montelukast) (OR $11.63[2.62 ; 52.63])$. The type of GP location was associated with whether the GP referred the infant to hospital only once feeding was $<50 \%$ of normal. GPs in rural regions were more likely to refer infants if feeding was still more than $50 \%$ of normal. Compared with GPs working in rural locations, GPs in urban areas were almost twice as likely to wait until feeding was $<50 \%$ before referring infants, although this was only weakly significant (OR 1.93 [0.99; 3.75]). GPs in semi-urban areas were more than twice as likely to refer infants only once feeding was $<50 \%$ of normal than GP's in rural locations (OR 2.34 [1.26; 4.42]).

\section{Discussion}


This study has demonstrated a wide variation in the guidelines and management of infants with bronchiolitis in primary care in the UK. Thirty-nine percent of GPs did not use any guideline to manage bronchiolitis, and of those that did the source of the guideline was variable. The NICE guideline aims to reduce this variation. ${ }^{10}$ However, despite the similar SIGN guideline ${ }^{9}$ having been available in Scotland (and also used in other regions of the UK) since 2006, management of bronchiolitis still varied considerably from that advised. Few studies have addressed the impact of a clinical guideline on the management of bronchiolitis in primary care. One study 11 in France demonstrated the introduction of a clinical guideline resulted in a small but significant reduction in the prescription of steroids, bronchodilators and mucolytics and a statistically significant $28 \%$ absolute increase (from $29 \%$ to $57 \%$ ) in the provision of "adequate general advice". There was no significant impact on the use of investigations. ${ }^{11}$ In our study use of 'inappropriate' medications ranged from $2-35 \%$ depending on the medication. We found $19 \%$ of GPs routinely prescribed oral steroids. This is concerning as there is good evidence oral steroids are of no benefit to infants with bronchiolitis ${ }^{6}$ (or indeed in most circumstances in the main differential diagnosis of viral induced wheeze ${ }^{12}$ ), and steroids potentially have a negative impact on growth and bone mineral density. ${ }^{13}$ Only $7 \%$ of GPs, however, routinely prescribed antibiotics.

In our study, factors that were demonstrated in multivariate analysis to be related to variation in management were the sex and year of qualification of the GP, whether the GP practice was a dispensing practice, the location and type 
of location of the GP practice and the number of GPs working in the practice. More experienced GPs were less likely to use a guideline, more likely to prescribe 'inappropriate' medications (oral steroids and antibiotics) and had a lower threshold for referral to hospital. This suggests more experienced GPs are either unfamiliar with newer evidence and clinical guidelines, are more confident in managing these patients but less risk averse, prescribe more for potential differential diagnoses, or give a prescription which is not clinically indicated. One study ${ }^{14}$, prior to the publication of the AAP bronchiolitis guideline in 2006, found that, although more experienced US paediatricians were less risk averse than more junior colleagues, how risk averse a paediatrician was had no impact on their rate of admitting infants with bronchiolitis.

We have also demonstrated different geographic areas were associated with marked variation in the primary care management of bronchiolitis. When comparing these factors with hospital admission rates by the same geographic areas from the study by Murray et al ${ }^{3}$ no clear pattern was identified. This suggests these factors individually are not associated with the geographic variation in hospitalisation rates, the geographic areas studied are too large to note local differences or other factors not easily measurable, for example, the overall subjective clinical and social "picture" of the child and family, may have a role irrespective of objective clinical parameters.

GPs working in dispensing practices were more likely to prescribe leukotriene receptor antagonists and those working in practices with fewer GPs were more 
likely to prescribe bronchodilators. A previous study ${ }^{15}$ which surveyed UK GPs found those working in dispensing practices, male GPs, GPs working in deprived areas, single-handed GPs, GP trainers and GPs with increased length of service had higher prescribing costs, similar to our findings for bronchiolitis. The explanation for these variations was multifactorial but could have included knowledge of alternative and newer medications, incentives to increase profitability through prescribing in dispensing practices and time pressure leading to "giving a prescription which is not clinically indicated". ${ }^{15}$ The less time a GP has with the patient, the less carefully they are able assess clinical parameters, the less time they spend explaining the diagnosis and possible outcomes to the family, and the more likely they are to prescribed an "inappropriate" medication to expedite the completion of the consultation. "Inappropriate" prescriptions add to healthcare costs and can worsen outcome (e.g. the potential for worsening oxygen saturations if an infant struggles against an inhaler mask pressed on the face). In addition, a poor explanation of the condition to the family may result in increased costs as either parents may seek further, unnecessary healthcare reviews or not reattend soon enough if their child deteriorates and therefore require more intensive management.

This study has a number of strengths. We have undertaken the largest survey of UK GPs investigating the management of bronchiolitis. We surveyed over 1000 GPs with a representative geographic distribution across the UK. We included GPs with a wide range of experiences in a variety of settings and thus were able to assess the relationship various GP factors had on the management strategies used. The study also had several weaknesses. The 
GPs were recruited through Doctors.net.uk and may not necessarily be representative of all GPs. In particular, we did not include trainee GPs. This methodology, however, has been used previously to survey GPs in the UK. ${ }^{16},{ }^{17}$ We did not look at individual patient notes and thus cannot comment on whether what GPs reported they did actually manifest in patient care. We may have, therefore, over- or under-estimated guidance suggesting the use of medications and investigations.

In conclusion, we have shown wide variation in the guidelines and management of infants with bronchiolitis in primary care in the UK and provided a benchmark against which future studies can be assessed. Many GPs were not compliant with the new NICE guideline prior to its publication meaning they need to update their guidelines and practices. We welcome the new NICE guideline, however, ensuring it is widely implemented and adhered to will be challenging. As has been shown in the USA with the AAP bronchiolitis guideline ${ }^{18}$, publishing a national guideline does not necessarily result in high compliance with it. We plan to carry out repeat surveys of GPs to assess the impact of the NICE guideline in its first years after implementation.

\section{Contributorship}

SBD and AJP designed the study. SBD and EPG devised the surveys. SBD and $\mathrm{AN}$ analysed the data. SBD wrote the initial draft and all authors revised the draft.

\section{Acknowledgements}


This study was funded by the Medical Sciences Division Medical Research Fund and the Jenner Institute of the University of Oxford. The funders had no role in the design, data collection or analysis, interpretation, write up or decision for article submission of the project. We wish to thank the general practitioners who completed the survey and MedeConnect for collecting the data.

\section{References}

1. Green CA, Yeates D, Goldacre A, et al. Admission to hospital for bronchiolitis in England: trends over five decades, geographical variation and association with perinatal characteristics and subsequent asthma. Arch Dis Child 2016; 101(2):140-6.

2. Cheung $\mathrm{CR}$, Smith $\mathrm{H}$, Thurland $\mathrm{K}$, et al. Population variation in admission rates and duration of inpatient stay for bronchiolitis in England. Arch Dis Child 2013; 98: 57-59

3. Murray J, Bottle A, Sharland M, et al. Risk factors for hospital admission with RSV bronchiolitis in England: a population-based birth cohort study. PLoS One 2014; 9: e89186.

4. Gadomski A, Scribani M. Bronchodilators for bronchiolitis. Cochrane Database Syst Rev 2014;6:CD001266.

5. Farley R, Gkp S, Eriksson L, Cb DM. Antibiotics for bronchiolitis in children under two years of age. Cochrane Database Syst Rev 2014;10:CD005189.

6. Fernandes RM, Bialy LM, Vandermeer B, et al. Glucocorticoids for acute viral bronchiolitis in infants and young children. Cochrane Database Syst Rev 10;2010:CD004878. 
7. Liu F, Ouyang J, Sharma AN, et al. Leukotriene inhibitors for bronchiolitis in infants and young children. Cochrane Database Syst Rev 2015; 3: CD010636.

8. Murray J, Saxena S, Sharland M. Preventing severe respiratory syncytial virus disease: passive, active immunisation and new antivirals. Arch Dis Child 2014; 99: 469-473.

9. SIGN. Bronchiolitis in Children- Sign Guideline 91 (2006).

10. National Institute for Health and Care Excellence. Bronchiolitis: diagnosis and management of bronchiolitis in children. Clinical Guideline NG 9. 2015.

11. Touzet S, Réfabert $L$, Letrilliart $L$, et al. Impact of consensus development conference guidelines on primary care of bronchiolitis: Are national guidelines being followed? J Eval Clin Pract 2007; 13: 651-656.

12. Bush A, Grigg J, Saglani S. Managing wheeze in preschool children. Brit Med J 2014; 348: g15-g15.

13. Guilbert TW, Morgan WJ, Zeiger RS, et al. Long-Term Inhaled Corticosteroids in Preschool Children at High Risk for Asthma. N Engl J Med 2006; 354: 1985-1997.

14. Baldwin RL, Green JW, Shaw JL, et al. Physician risk attitudes and hospitalization of infants with bronchiolitis. Acad Emerg Med 2005; 12: $142-$ 146.

15. Watkins C, Harvey I, Carthy P, et al. Attitudes and behaviour of general practitioners and their prescribing costs: a national cross sectional survey. Qual Saf Health Care 2003; 12: 29-34. 
16. Plüddemann A, Wallace $\mathrm{E}$, Bankhead $\mathrm{C}$, et al. Clinical prediction rules in practice: Review of clinical guidelines and survey of GPs. Br J Gen Pract $2014 ; 64:$ 233-242.

17. Ahmad S, Orrell M, lliffe S, et al. GPs' attitudes, awareness, and practice regarding early diagnosis of dementia. Br J Gen Pract 2010; 60: 360-365.

18. Parikh K, Hall M, Teach SJ. Bronchiolitis management before and after the AAP guidelines. Pediatrics 2014; 133: e1-e7.

Table 1: Percentage of GPs compliant with the NICE guideline by country

\begin{tabular}{|c|c|c|c|c|c|c|}
\hline & $\begin{array}{c}\text { Total } \\
(\%)\end{array}$ & $\begin{array}{c}\text { England } \\
(\%)\end{array}$ & $\begin{array}{c}\text { Scotland } \\
(\%)\end{array}$ & $\begin{array}{c}\text { Wales } \\
(\%)\end{array}$ & $\begin{array}{l}\mathrm{NI} \\
(\%)\end{array}$ & $P^{*}$ \\
\hline $\begin{array}{l}\text { Hospital referral if oxygen } \\
\text { saturations } \leq 92 \% \text { (excluding } \\
\text { those who only referred once } \\
\text { saturations } \leq 90 \% \text { or } \leq 88 \% \text { ) }\end{array}$ & 25 & 26 & 17 & 14 & 30 & 0.40 \\
\hline $\begin{array}{l}\text { Hospital referral if feeding }<50 \% \\
\text { (excluding those who only } \\
\text { referred once feeding }<33 \% \text { ) }\end{array}$ & 56 & 55 & 62 & 57 & 63 & 0.18 \\
\hline Use of antibiotics & 93 & 93 & 94 & 91 & 81 & 0.10 \\
\hline Use of inhaled bronchodilator & 65 & 64 & 78 & 67 & 48 & 0.01 \\
\hline Use of oral steroid & 81 & 80 & 80 & 84 & 78 & 0.95 \\
\hline
\end{tabular}




$\begin{array}{lcccccc}\text { Use of inhaled steroid } & 95 & 95 & 95 & 94 & 89 & 0.58 \\ \text { Use of montelukast } & 98 & 98 & 99 & 100 & 96 & 0.70 \\ \text { Providing an advice sheet } & \mathbf{3 8} & 40 & 27 & 29 & 44 & 0.03\end{array}$

*The $\mathrm{P}$ values compare proportions across the four countries.

${ }^{* *}$ If using the SIGN guideline (referral to hospital if oxygen saturations <95\%) then the compliance was 34\% England, 46\% Scotland, 39\% Wales, $41 \%$ Northern Ireland and $36 \%$ overall, $\mathrm{P}=0.13$.

\section{Benchmarking of viral bronchiolitis management by General Practitioners (GPs) in the UK - supplementary material}

Supplementary box 1: The five research questions GPs were asked

Question 1: Which protocols or guidelines for managing infants up to one year old with viral bronchiolitis (e.g. for diagnostic criteria, guidelines for hospital referral) do you use?

Please select all that apply 
- Locally developed (e.g. local GP practice, CCG, local hospital)

- Commercial (e.g. GP notebook, other similar internet guidance)

- National (e.g. SIGN, AAP)

- None of the above

Question 2: At approximately what level of oxygen saturation in infants up to one year old with viral bronchiolitis do you routinely refer to hospital?

Please select one option

- $\leq 88 \%$ (i.e. if oxygen saturations are $88 \%$ or less I would refer to hospital)

- $\leq 90 \%$ (i.e. if oxygen saturations are $90 \%$ or less I would refer to hospital)

- $\leq 92 \%$ (i.e. if oxygen saturations are $92 \%$ or less I would refer to hospital)

- $\leq 94 \%$ (i.e. if oxygen saturations are $94 \%$ or less I would refer to hospital)

- I do not test oxygen saturation on infants with viral bronchiolitis

Question 3: At approximately what amount of feeding in infants up to one year old with viral bronchiolitis do you routinely refer to hospital (if no other requirements for referral)?

Please select one option

- $<33 \%$ (i.e. feeding less one third of normal)

- $<50 \%$ (i.e. feeding less than half of normal)

- $<66 \%$ (i.e. feeding less than two thirds of normal)

- $<75 \%$ (i.e. feeding less than three quarters of normal)

- $<100 \%$ (i.e. feeding anything less than normal)

Question 4: For infants up to one year old with viral bronchiolitis do you routinely prescribe any of these medicines?

Please select all that apply

- Inhaled bronchodilator

- Inhaled steroid

- Oral steroid

- Oral antibiotic

- Oral Leukotriene Receptor Antagonist (e.g. montelukast)

- Saline (or similar) nose drops

- None of the above

Question 5: Do you routinely provide any written guidance for parents of infants up to one year old diagnosed with viral bronchiolitis?

Please select all that apply

- Locally developed (e.g. GP surgery, clinical commissioning group, hospital)

- National (e.g. NHS leaflet)?

- Other (please specify)

- I do not provide guidance for viral bronchiolitis 
Supplementary table 1: The geographic areas where participating GPs practice

\begin{tabular}{|c|c|c|}
\hline Area & $\mathbf{n}$ & $\%$ \\
\hline England & 825 & $82 \%$ \\
\hline London & 122 & $12 \%$ \\
\hline South East & 66 & $7 \%$ \\
\hline South Central & 71 & $7 \%$ \\
\hline South West & 94 & $9 \%$ \\
\hline West Midlands & 84 & $8 \%$ \\
\hline East Midlands & 66 & $7 \%$ \\
\hline East of England & 86 & $9 \%$ \\
\hline Yorkshire \& Humber & 83 & $8 \%$ \\
\hline North East & 43 & $4 \%$ \\
\hline North West & 110 & $11 \%$ \\
\hline Scotland & 100 & $10 \%$ \\
\hline Wales & 49 & $5 \%$ \\
\hline Northern Ireland & 27 & $3 \%$ \\
\hline Total & 1001 & $100 \%$ \\
\hline
\end{tabular}


Supplementary table 2: Results from multivariate logistic regression for dichotomised outcomes.

Data are presented as Wald statistic (degrees of freedom) (P value).

\begin{tabular}{|c|c|c|c|c|c|c|c|c|c|c|c|c|}
\hline & $\begin{array}{l}\text { Use } \\
\text { guideline? }\end{array}$ & $\begin{array}{l}\text { Use } \mathrm{O}_{2} \text { sats } \\
\text { monitoring? }\end{array}$ & $\begin{array}{l}\text { Refer if } \mathrm{O}_{2} \\
\text { sats } \\
<92 \% \text { ? }\end{array}$ & $\begin{array}{l}\text { Refer if } \\
\text { feeding } \\
<50 \% \text { ? }\end{array}$ & $\begin{array}{l}\text { Prescribe } \\
\text { salbutamol? }\end{array}$ & $\begin{array}{l}\text { Prescribe } \\
\text { inhaled } \\
\text { steroid? }\end{array}$ & $\begin{array}{l}\text { Prescribe } \\
\text { oral } \\
\text { steroid? }\end{array}$ & $\begin{array}{l}\text { Prescribe } \\
\text { antibiotics? }\end{array}$ & $\begin{array}{l}\text { Prescribe } \\
\text { montelukast } \\
?\end{array}$ & $\begin{array}{l}\text { Prescribe } \\
\text { saline nose } \\
\text { drops? }\end{array}$ & $\begin{array}{l}\text { Prescribe any } \\
\text { 'inappropriate' } \\
\text { meds? }\end{array}$ & $\begin{array}{l}\text { Provide written } \\
\text { advice? }\end{array}$ \\
\hline Sex & $\begin{array}{l}0.073(1) \\
(0.787)\end{array}$ & $\begin{array}{l}0.251(1) \\
(0.616)\end{array}$ & $\begin{array}{l}23.248(1) \\
\left(1 \times 10^{-6}\right)\end{array}$ & $\begin{array}{l}6.491(1) \\
(0.011)\end{array}$ & $\begin{array}{l}0.309(1) \\
(0.578)\end{array}$ & $\begin{array}{l}0.830(1) \\
(0.362)\end{array}$ & $\begin{array}{l}0.150(1) \\
(0.698)\end{array}$ & $\begin{array}{l}1.354(1) \\
(0.245)\end{array}$ & $\begin{array}{l}1.763(1) \\
(0.184)\end{array}$ & $\begin{array}{l}0.737(1) \\
(0.391)\end{array}$ & $\begin{array}{l}0.072(1) \\
(0.788)\end{array}$ & $\begin{array}{l}0.838(1) \\
(0.360)\end{array}$ \\
\hline $\begin{array}{l}\text { Number Patients at a } \\
\text { GP practice }\end{array}$ & $\begin{array}{l}0.001(1) \\
(0.970)\end{array}$ & $\begin{array}{l}0.027(1) \\
(0.869)\end{array}$ & $\begin{array}{l}0.298(1) \\
(0.585)\end{array}$ & $\begin{array}{l}0.195(1) \\
(0.659)\end{array}$ & $\begin{array}{l}2.812(1) \\
(0.094)\end{array}$ & $\begin{array}{l}0.880(1) \\
(0.348)\end{array}$ & $\begin{array}{l}0.535(1) \\
(0.464)\end{array}$ & $\begin{array}{l}0.231(1) \\
(0.631)\end{array}$ & $\begin{array}{l}1.176(1) \\
(0.278)\end{array}$ & $\begin{array}{l}0.566(1) \\
(0.452)\end{array}$ & $\begin{array}{l}0.404(1) \\
(0.525)\end{array}$ & $\begin{array}{l}0.030(1) \\
(0.863)\end{array}$ \\
\hline $\begin{array}{l}\text { Number Doctors at a } \\
\text { GP practice }\end{array}$ & $\begin{array}{l}0.050(1) \\
(0.824)\end{array}$ & $\begin{array}{l}0.000(1) \\
(0.990)\end{array}$ & $\begin{array}{l}8.705(1) \\
(0.003)\end{array}$ & $\begin{array}{l}0.379(1) \\
(0.538)\end{array}$ & $\begin{array}{l}4.800(1) \\
(0.028)\end{array}$ & $\begin{array}{l}1.002(1) \\
(0.317)\end{array}$ & $\begin{array}{l}0.001(1) \\
(0.971)\end{array}$ & $\begin{array}{l}1.228(1) \\
(0.268)\end{array}$ & $\begin{array}{l}0.522(1) \\
(0.470)\end{array}$ & $\begin{array}{l}2.063(1) \\
(0.151)\end{array}$ & $\begin{array}{l}2.860(1) \\
(0.091)\end{array}$ & $\begin{array}{l}0.206(1) \\
(0.650)\end{array}$ \\
\hline Dispensing Practice & $\begin{array}{l}0.061(1) \\
(0.805)\end{array}$ & $\begin{array}{l}0.002(1) \\
(0.962)\end{array}$ & $\begin{array}{l}0.003(1) \\
(0.956)\end{array}$ & $\begin{array}{l}0.005(1) \\
(0.943)\end{array}$ & $\begin{array}{l}0.197(1) \\
(0.657)\end{array}$ & $\begin{array}{l}0.784(1) \\
(0.376)\end{array}$ & $\begin{array}{l}1.453(1) \\
(0.228)\end{array}$ & $\begin{array}{l}1.630(1) \\
(0.202)\end{array}$ & $\begin{array}{l}10.387(1) \\
(0.001)\end{array}$ & $\begin{array}{l}2.247(1) \\
(0.134)\end{array}$ & $\begin{array}{l}0.429(1) \\
(0.513)\end{array}$ & $\begin{array}{l}2.098(1) \\
(0.147)\end{array}$ \\
\hline Role of GP & $\begin{array}{l}4.207(3) \\
(0.240)\end{array}$ & $\begin{array}{l}6.311(3) \\
(0.097)\end{array}$ & $\begin{array}{l}0.681(3) \\
(0.878)\end{array}$ & $\begin{array}{l}3.980(3) \\
(0.264)\end{array}$ & $\begin{array}{l}3.068(3) \\
(0.381)\end{array}$ & $\begin{array}{l}0.246(3) \\
(0.970)\end{array}$ & $\begin{array}{l}7.129(3) \\
(0.068)\end{array}$ & $\begin{array}{l}2.364(3) \\
(0.500)\end{array}$ & $\begin{array}{l}1.395(3) \\
(0.707)\end{array}$ & $\begin{array}{l}0.333(3) \\
(0.954)\end{array}$ & $\begin{array}{l}6.533(3) \\
(0.088)\end{array}$ & $\begin{array}{l}3.455(3) \\
(0.327)\end{array}$ \\
\hline Year Qualified & $\begin{array}{l}37.057(3) \\
(<0.001)\end{array}$ & $\begin{array}{l}1.666(3) \\
(0.645)\end{array}$ & $\begin{array}{l}0.832(3) \\
(0.842)\end{array}$ & $\begin{array}{l}43.475(3) \\
\left(2.0 \times 10^{-9}\right)\end{array}$ & $\begin{array}{l}0.607(3) \\
(0.895)\end{array}$ & $\begin{array}{l}6.298(3) \\
(0.098)\end{array}$ & $\begin{array}{l}10.117(3) \\
(0.018)\end{array}$ & $\begin{array}{l}13.976(3) \\
(0.003)\end{array}$ & $\begin{array}{l}2.003(3) \\
(0.572)\end{array}$ & $\begin{array}{l}6.814(3) \\
(0.078)\end{array}$ & $\begin{array}{l}9.654(3) \\
(0.022)\end{array}$ & $\begin{array}{l}13.490(3) \\
(0.004)\end{array}$ \\
\hline Type of GP Location & $\begin{array}{l}2.379(4) \\
(0.666)\end{array}$ & $\begin{array}{l}4.286(4) \\
(0.369)\end{array}$ & $\begin{array}{l}2.677(4) \\
(0.613)\end{array}$ & $\begin{array}{l}9.586(4) \\
(0.048)\end{array}$ & $\begin{array}{l}2.804(4) \\
(0.591)\end{array}$ & $\begin{array}{l}3.238(4) \\
(0.519)\end{array}$ & $\begin{array}{l}1.204(4) \\
(0.877)\end{array}$ & $\begin{array}{l}1.894(4) \\
(0.755)\end{array}$ & $\begin{array}{l}4.401(4) \\
(0.354)\end{array}$ & $\begin{array}{l}4.173(4) \\
(0.383)\end{array}$ & $\begin{array}{l}1.132(4) \\
(0.889)\end{array}$ & $\begin{array}{l}3.692(4) \\
(0.449)\end{array}$ \\
\hline $\begin{array}{l}\text { Region of the UK of } \\
\text { GP practice }\end{array}$ & $\begin{array}{l}11.926(12) \\
(0.452)\end{array}$ & $\begin{array}{l}21.897(12) \\
(0.039)\end{array}$ & $\begin{array}{l}18.893(12) \\
(0.091)\end{array}$ & $\begin{array}{l}13.898(12) \\
(0.307)\end{array}$ & $\begin{array}{l}25.297(12) \\
(0.013)\end{array}$ & $\begin{array}{l}7.883(12) \\
(0.794)\end{array}$ & $\begin{array}{l}13.272(2) \\
(0.350)\end{array}$ & $\begin{array}{l}17.012(12) \\
(0.149)\end{array}$ & $\begin{array}{l}4.078(12) \\
(0.982)\end{array}$ & $\begin{array}{l}30.587(12) \\
(0.002)\end{array}$ & $\begin{array}{l}28.346(12) \\
(0.005)\end{array}$ & $\begin{array}{l}13.178(12) \\
(0.356)\end{array}$ \\
\hline
\end{tabular}


Supplementary figure 1(a-f): The percentage of GPs who (a) use a guideline, (b) routinely test oxygen saturations, (c) refer to hospital if oxygen saturations $\leq 92 \%$ (d) refer to hospital if feeding is at least $<50 \%$ of normal, (e) do not prescribe any 'inappropriate' medication, (f) provide written advice for parents, in infants with bronchiolitis by English NHS Strategic Health Authority and country, divided by quartiles. The rho and $\mathrm{P}$ value refer to the correlation between the percentage of GPs compliant with the variable and the regional hospital admission rate for viral bronchiolitis for infants less than one year old (using data from [3]).
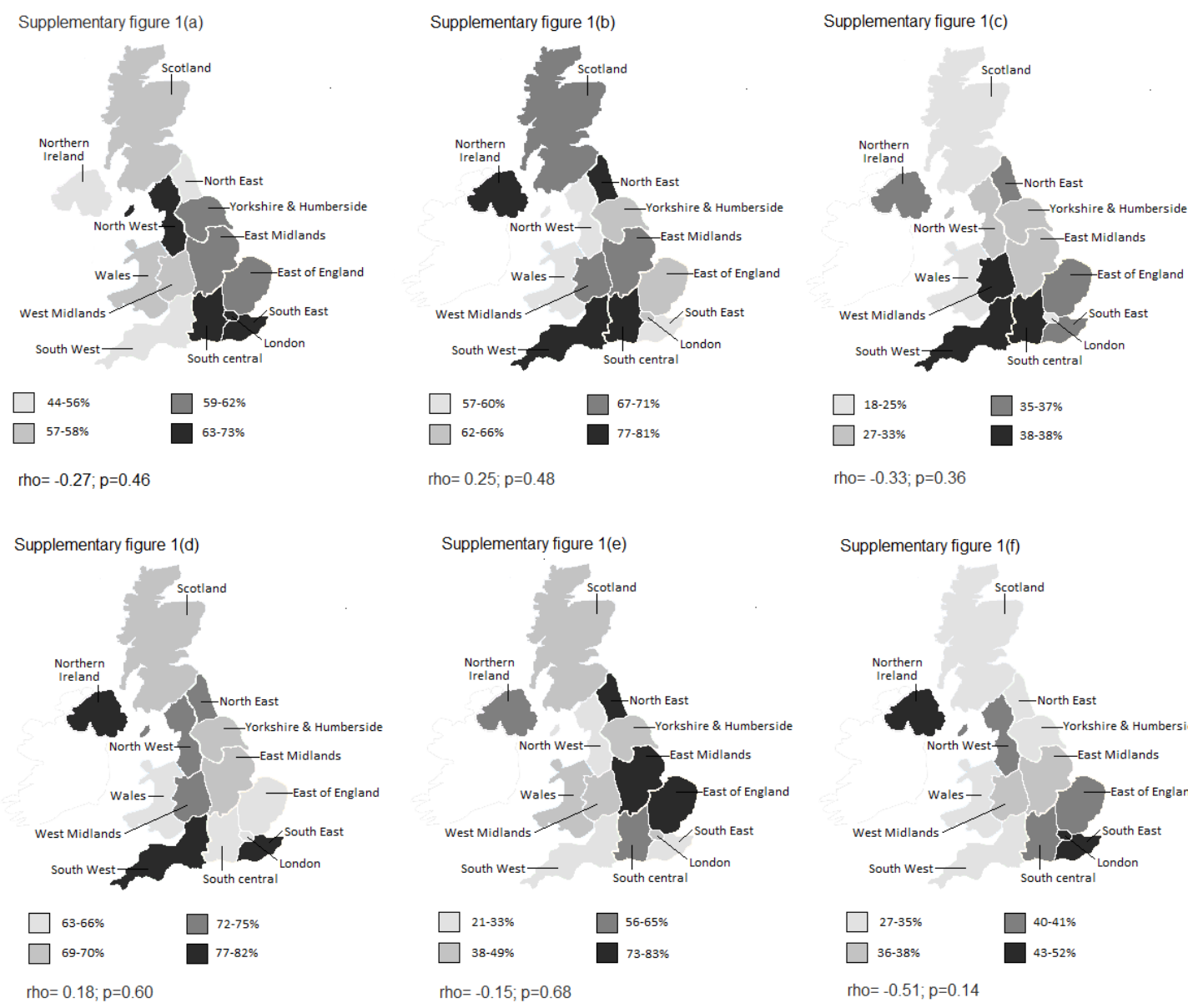

Supplementary figure 1 (f)

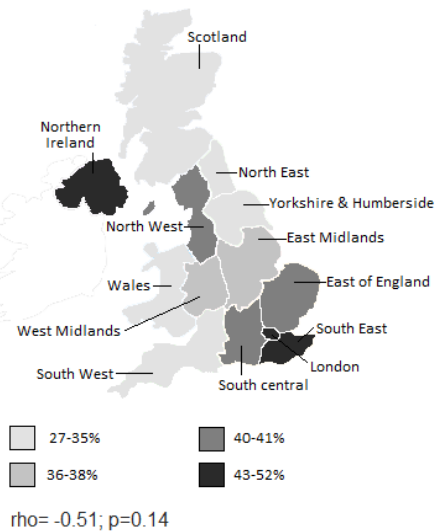


Supplementary figure 2: Proportion of bronchiolitis hospital admissions among birth cohort, by English NHS Strategic Health Authority of admission (created using data from Murray et al [3]).

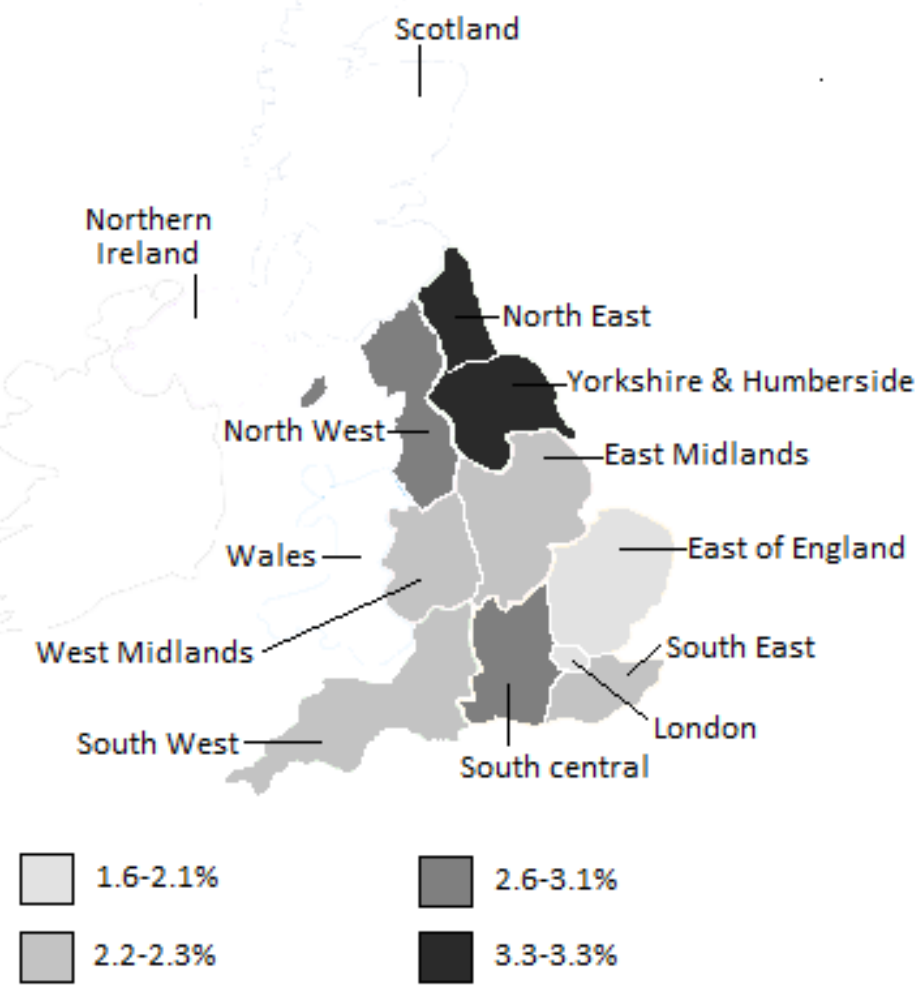

